DOI: https://doi.org/10.31933/jimt.v3i2 Received: 1 Oktober 2021, Revised: 15 Oktober 2021, Publish: 7 November 2021

JIMT
JURNAL ILMU MANAJEMEN
JINASTI

\title{
MENINGKATKAN CITRA PERBANKAN MELALUI CUSTOMER RELATIONSHIP MANAGEMENT PADA BNI KC SIMPANG RIMBO KOTA JAMBI
}

\author{
Gupron Gupron ${ }^{1}$ \\ ${ }^{1)}$ Fakultas Ekonomi Universitas Batanghari, Jambi, Indonesia, email: gupron @ unbari.ac.id
}

\section{Koresponden Penulis: Gupron}

\begin{abstract}
Abstrak: Tujuan penelitian ini adalah untuk menganalisis pengaruh customer relationship management terhadap citra perbankan baik secara simultan maupun parsial pada BNI KC Simpang Rimbo Kota Jambi. Populasi dalam penelitian ini adalah nasabah BNI KC Simpang Rimbo Kota Jambi yang berjumlah 9.359 nasabah sampai dengan tahun 2020. Besar atau jumlah sampel dalam penelitian ini ditentukan berdasarkan teori yang dikembangkan oleh Slovin dengan margin of error $10 \%$ sehingga suatu ukuran sampel dari 100 pelanggan diperoleh. Pendekatan dalam penelitian ini menggunakan pendekatan kuantitatif dengan metode survey dan menggunakan analisis data persamaan regresi linier berganda yang dibantu dengan software SPSS 23.0 for windows. Namun sebelum melakukan analisis, terlebih dahulu dilakukan uji kualitas data melalui uji validitas dan reliabilitas serta uji asumsi klasik. Kemudian uji hipotesis melalui uji t (parsial). Dari hasil analisis disimpulkan bahwa customer relationship management berpengaruh positif dan signifikan terhadap citra bank.
\end{abstract}

Kata Kunci: Customer Relationship Management dan Citra Bank.

\section{PENDAHULUAN}

Bank merupakan sebuah badan usaha yang menghimpun dana masyarakat, kemudian menempatkan dana tersebut berupa simpanan serta menyalurkannya kepada masyarakat kembali, baik dalam bentuk simpanan maupun berupa kredit. Selain itu dalam fungsi umum, bank pada dasarnya memiliki peranan sebagai sebuah badan penghimpunan dana, penyaluran, serta pelayanan jasa keuangan (Yandi, 2019).

Dalam menjalankan bisnisnya bank senantiasa mempertimbangkan beberapa aspek dalam membuat keputusan untuk memberikan pelayanan yang maksimal pada nasabah. Dimana beberapa aspek tersebut diantarnya yaitu citra bank itu sendiri. Citra merupakan persepsi masyarakat terahdap perusahaan atau produknya (Kotler dan Keller, 2012). Citra adalah persepsi atau cara pandang dari nasabah kepada pihak perusahaan yang berdasarkan atas atribut-atribut yang melekat pada perusahaan tersebut.

Citra perusahaan merupakan persepsi umum yang dipegang oleh suatu organisasi oleh suatu kelompok atau kelompok (Balmer, 1995) atau hasil bersih dari interaksi semua pengalaman, kesan, kepercayaan, perasaan, dan pengetahuan yang dimiliki orang tentang 
perusahaan (Worcester, 1997), telah menjadi fokus spesialis pemasaran, terutama di berbagai sektor jasa selama bertahun-tahun. Pentingnya citra perusahaan di sektor jasa keuangan terutama berasal dari fakta bahwa citra perusahaan dipandang sebagai instrumen yang kuat untuk mempengaruhi pelanggan. Dalam situasi ketika hanya ada sedikit perbedaan harga dan konsumen dibanjiri dengan volume informasi yang meningkat, citra sebagai kesan yang diciptakan pada waktu tertentu pada tingkat abstraksi tertentu (Cornelissen, 2000) semakin banyak mengasumsikan peran faktor yang membuat orientasi pelanggan secara subjektif lebih mudah dan keputusan mereka lebih sederhana. Selain itu, di sektor jasa keuangan perolehan citra perusahaan yang kuat merupakan jenis diferensiasi yang paling efektif (Balmer \& Stotvig, 1997).

Salah satu faktor berikutnya yang dapat membentuk citra bank adalah customer relationship management (CRM). Hal ini dikemukakan oleh Setyaleksana, B.Y., Suharyono., dan Yulianto, E (2017) dalam penelitiannya yang mengungkapkan bahwa CRM dapat membentuk citra perusahaan yang positif di benak pelanggan. Selain itu Kamaludin., Tjuparmah, Y., dan Silvana, H (2019) dalam penelitiannya juga menyimpulkan bahwa terdapat pengaruh yang positif dan signifikan dari customer relationship management terhadap citra UPT Perpustakaan Institut Teknologi Bandung baik dari aspek data dan teknologi, sumber daya manusia, maupun proses customer relationship management.

CRM merupakan proses dan strategi yang digunakan perusahaan dalam memperoleh, mengidentifikasi, dan mempertahankan pelanggan dalam rangka menciptakan nilai unggul bagi perusahaan serta bertujuan untuk membangun dan memelihara hubungan jangka panjang dengan pelanggan (Adikaram \& Khatabi, 2016). Selain itu CRM juga bertujuan untuk memahami kebutuhan pelanggan, memperlakukan pelanggan sebagai mitra, serta menjamin kebutuhan pelanggan melalui kualitas pelayanan yang baik yang diberikan oleh karyawan kepada pelanggan (Evans dan Lanskin, 2006).

Selain sebagai sebuah strategi, CRM juga merupakan strategi inti yang menyelaraskan antara proses dan fungsi internal, jaringan eksternal dalam rangka menciptakan serta menyampaikan nilai kepada pelanggan untuk mendapatkan keuntungan bagi perusahaan (Buttle, 2007). Menurut Al-dmour \& Hayat (2019) CRM digunakan sebagai proses menciptakan dan memelihara hubungan dengan konsumen, yang bertujuan untuk memuaskan dan membangun hubungan jangka panjang dengan pelanggan. Penerapan CRM di perusahaan sangat penting dalam mengarahkan kecenderungan pelanggan untuk berkomitmen dan menjaga hubungan dengan perusahaan (Balaji, 2015). Agar peneliti mempunyai arah yang jelas, maka ditetapkan tujuan penelitian yaitu untuk menganalisis pengaruh customer relationship management terhadap citra bank.

Citra adalah apa yang konsumen pikir atau rasakan ketika mereka mendengar atau melihat nama suatu merek atau pada intinya apa yang konsumen telah pelajari tentang merek (Supranto, 2011). Menurut Simamora (2007) bahwa citra adalah persepsi yang relatif konsisten dalam jangka panjang (enduring perception) maka tidak mudah untuk membentuk citra, sehingga bila telah terbentuk akan sulit mengubahnya. Menurut Ali, H (2012) image is the result of evaluation in a person based on perception and understanding of the image that has been processed, organized, and stored in one's mind. Image can be measured through a person's opinion, impression or response with the aim of knowing exactly what is in the mind of each individual about an object, how they understand it, and what they like or dislike about the object.

Citra perusahaan yang baik merupakan sebuah asset bagi kebanyakan perusahaan karena citra perusahaan memiliki sesuatu dampak terhadap persepsi pelanggan dari komunikasi dan operasi perusahaan yang sangat menghormati pelanggan. Gronroos (2001) menyebutkan citra memiliki dua fungsi yaitu: 1) citra perusahaan merupakan komunikasi 
dengan berbagai harapan; dan 2) citra perusahaan merupakan sebuah fungsi dari pengalaman yang paling baik sebagai mana berbagai harapan pelanggan.

Menurut Sciffman dan Kanuk (2010) ada beberapa faktor pembentuk citra, yaitu sebagai berikut: 1) Kualitas dan mutu, berkaitan dengan kualitas produk barang yang ditawarkan oleh produsen dengan merek tertentu; 2) Dapat dipercaya atau diandalkan, berkaitan dengan pendapat atau kesepakatan yang dibentuk oleh masyarakat tentang suatu produk yang dikonsumsi; 3) Kegunaan atau manfaat, yang terkait dengan fungsi dari suatu produk yang bisa dimanfaatkan oleh konsumen; 4) Pelayanan, yang terkait dengan tugas produsen dalam melayani konsumennya; 5) Resiko, terkait dengan besar kecilnya akibat untung dan rugi yang mungkin dialami oleh konsumen; 6) Harga, yang dalam hal ini berkaitan dengan tinggi rendahnya atau banyak sedikitnya jumlah uang yang dikeluarkan oleh konsumen untuk mempengaruhi suatu produk, juga dapat mempengaruhi citra jangka panjang; dan 7) Citra yang dimiliki oleh merek itu sendiri, yaitu berupa pandangan, kesepakatan, dan informasi yang berkaitan dengan suatu merek dari produk tertentu.

Menurut Flavian, Torres dan Guinaliu dalam Ali, H (2012) dalam penelitiannya mengenai pengukuran citra perbankan dihasilkan empat elemen yang dapat membentuk citra perbankan, yaitu acces to services, service offered, personal contact, security dan reputation, yang akan digunakan pada penelitian ini.

Secara umum Customer Relationship Management (CRM) atau manajemen hubungan pelanggan dapat diartikan sebagai proses dalam mengidentifikasi, menarik, dan mempertahankan pelanggan (anggota) guna untuk menciptakan nilai pelanggan Customer Value (Tjiptono, 2011). CRM merupakan kegiatan yang dilakukan untuk menangani hubungan antara lembaga dengan anggota yang bertujuan untuk meningkatkan nilai perusahaan di mata anggota. Hubungan dengan pelanggan (anggota) sangatlah penting bagi sebuah lembaga. Sebab, tanpa pelanggan (anggota) lembaga tersebut tidak akan bisa menjalankan tujuan mereka.

CRM adalah suatu strategi untuk mengidentifikasi, menarik, dan mempertahankan konsumen yang paling bernilai bagi perusahaan. CRM berkonsentrasi pada apa yang konsumen nilai, bukan pada apa yang perusahaan ingin jual (Tunggal, 2008). Sedangkan menurut Moore (2005) CRM adalah suatu cara mengkomputerisasi bisnis, pihak lain menyebut CRM adalah suatu rangkaian tehnik dan alat untuk menangani konsumen. CRM adalah usaha sebuah perusahaan untuk berkonsentrasi menjaga konsumen (supaya tidak lari ke pesaing) dengan mengumpulkan segala bentuk interaksi konsumen baik itu lewat telepon, email, masukan di situs atau hasil pembicaraan dengan staf sales dan marketing, atau CRM adalah sebuah strategi bisnis menyeluruh dari suatu perusahaan yang memungkinkan perusahaan tersebut secara efektif bisa mengelola hubungan dengan para konsumen (Iriandini, A.P., Yulianto, E., dan Mawardi, M.K., 2015).

Menurut Buttle (2007) terdapat 3 hal yang dapat menjadi terbentuknya pengembangan dan penerapan strategi CRM sebagai berikut: 1) Keintiman Pelanggan (Customer Intimacy); 2) Menciptakan Nilai Pelanggan (Customer Value); dan 3) Perawatan Pelanggan (Customer Retention). Sedangkan menurut Ndubisi (2007) customer relationship management terdiri atas tiga yaitu komunikasi, komitmen, dan kepercayaan.

\section{METODE PENELITIAN}

Populasi dalam penelitian ini adalah nasabah BNI KC Simpang Rimbo Kota Jambi dengan jumlah sebanyak 9.359 pada tahun 2020. Sampel pada penelitian ini diambil dengan menggunakan formula Slovin dengan margin error 10\%, sehingga diperoleh sampel sebesar 98,94 dan di bulatkan menjadi 100 . 
Penelitian ini merupakan penelitian kuantitatif, karena data yang diperoleh berupa angka. Jenis penelitiannya adalah kuesioner dan metode yang digunakan tentang fenomena yang terjadi, prosesnya berupa pengumpulan dan penyusunan data serta analisis data. Data dikumpulkan melalui pengisian kuesioner dan dianalisis lebih lanjut. Penelitian ini terdiri atas 2 (dua variabel), yaitu variabel eksogen (CRM), terhadap variabel endogen citra perbankan.

Untuk menjawab semua tujuan pada penelitian ini, penulis menggunakan persamaan regresi linear berganda sebagai teknik analisis, dengan formula $\mathrm{Y}=\mathrm{a}+\mathrm{b} \cdot \mathrm{x}+\mathrm{e}$, dimana $\mathrm{Y}$ adalah variable citra bank, " $b$ " koefisien variable customer relationship management $(\mathrm{X})$. Guna mempermudah proses analisis data pada penelitian ini, penulis menggunakan aplikasi SPSS versi 21.0 for windows sebagai alat bantu analisis.

Setelah data diproses, langkah selanjutnya yaitu melakukan uji hipotesis melalui uji t untuk melakukan pengujian hipotesi secara parsial, dan uji $\mathrm{F}$ untuk melakukan pengujian secara simultan, dengan margin error yang ditetapkan sebesar 5\%. Namun sebelum dilakukan pengujian hipotesis, terlebih dahulu dilakukan uji instrument penelitian melalui uji validitas dan uji reliabilitas, serta melakukan uji asumsi klasik melalui uji normalitas, multikolinearitas, dan heterokedastisitas.

\section{HASIL DAN PEMBAHASAN}

Dari hasil survey yang dilakukan, pada dasarnya responden memberikan tanggapan setuju dan sangat setuju atas pernyataan yang diajukan pada setiap butir pernyataan yang ada pada kuesioner. Hal ini menjelaskan bahwa citra bank, kualitas layanan, dan customer relationship management telah sesuai dengan persepsi responden. Berdasarkan hasil analisis didapatkan bahwa:

1) Dari hasil survey yang dilakukan dapat disimpulkan bahwa citra bank BNI KC Simpang Rimbo Kota Jambi memiliki citra yang cukup kuat di mata masyarakat. Dimana citra itu tampak dari akses pelayanannya yang baik yakni kemudahan dalam menggunakan layanan, ketepatan waktu transaksi, kenyamanan pelayanan, jadwal operasional bank, dan kemungkinan untuk mengajukan keluhan/protes. Selain itu dari jasa yang ditawarkan tersedianya jumlah produk dan jasa, daya tarik produk dan jasa yang ditawarkan, ketertarikan produk jasa simpanan, ketertarikan pembayaran pinjaman, dan pembayaran biaya pelayanan.

2) Dari hasil survey yang dilakukan dapat disimpulkan bahwa customer relationship managament yang ada pada BNI KC Simpang Rimbo Kota Jambi dinilai telah berlangsung dengan baik. Dengan selalu menjalin komunikasi yang baik dengan nasabahnya, senantiasa komitmen pada nasabahnya memberikan pelayanan terbaik, serta terus berupaya membangun kepercayaan bagi nasabahnya untuk senantiasa selalu menggunakan jasa bank BNI.

Persamaan regresi yang baik pada dasarnya harus memenuhi beberapa asumsi yang menjadi persyaratan analisis regresi. Artinya persamaan regresi yang baik haruslah berdistribusi normal, tidak terjadi korelasi antar variable independent, serta tidak terjadi heterokedastisitas, melainkan data haruslah homogen. Adapun masing-masig pengujian tersebut akan di uraikan satu persatu sebagai berikut.

1. Dari pengujian normalitas yang dilakukan melalui one Sample Kolmogorov Smirnov Test diperoleh nilai signifikan sebesar 0,564 . Secara teori jika nilai signifikan yang di peroleh $>5 \%$ maka data dinyatakan berdistribusi normal. Dikarenakan nilai signifikan yang diperoleh sebesar $0,564>5 \%$, dengan ini maka dapat dinyatakan bahwa data pada 
penelitian ini telah berdistribusi normal, sehingga bisa untuk dilanjutkan pada tahap berikutnya.

2. Uji asumsi berikutnya yang menjadi syarat persamaan regresi linear sederhana melalui uji heterokedastisitas. Secara teori persamaan regresi yang baik tidak terjadi heterokedastisitas, melain terjadi homogenitas. Dimana hasil uji heterokedastisitas dapat di deteksi melalui scatterplots, dengan melihat penyebaran titik-titik plotnya. Jika titik-titik plotnya menyebar secara acak serta tersebar baik diatas maupun dibawah angka 0 pada sumbu Y, maka dapat disimpulkan tidak terjadi heterokedastisitas pada model regresi. Dikarenakan titik-titik plot pada penelitian ini menyebar secara acak serta tersebar baik diatas maupun dibawah angka 0 pada sumbu Y, sehingga model regresi layak dipakai untuk memprediksi Penggunaan jasa akomodasi berdasarkan masukan variabel independent.

Dari hasil uji asumsi yang dilakukan semuanya telah terpenuhi, sehingga model persamaan regresi dianggap baik dan dapat dilanjutkan untuk tahap berikutnya, yaitu dengan melakukan uji regresi dan pengujian hipotesis. Adapun dari pengolahan data yang dilakukan dengan menggunakan SPSS 23.0 for windows, di peroleh outputnya sebagai berikut.

Table 1

Hasil Analisa Regresi Linear Berganda

\begin{tabular}{|c|l|r|r|r|r|}
\hline $\begin{array}{c}\text { Variabel } \\
\text { Terikat }\end{array}$ & Variabel Bebas & $\begin{array}{c}\text { Koefisien } \\
\text { Regresi }\end{array}$ & thitung & Signifikansi & $\begin{array}{c}\text { Keputusan } \\
\text { Hipotesis }\end{array}$ \\
\hline $\begin{array}{c}\text { Citra Bank } \\
(Y)\end{array}$ & Konstanta (a) & 15,636 & & & - \\
\cline { 2 - 6 } & CRM (X) & 1,034 & 7,532 & 0,000 & Diterima \\
\cline { 2 - 6 } & Adjusted R ${ }^{2}$ & \multicolumn{3}{|c}{} & 0,360 \\
\hline & $\mathrm{t}_{\text {tabel }}$ & \multicolumn{3}{|c}{1,984} \\
\hline
\end{tabular}

Sumber: Output SPSS 23.0 for windows.

Dari tabel 1 di atas diperoleh hasil persamaan regresi linear berganda : $\mathrm{Y}=\mathrm{a}+\mathrm{b} \cdot \mathrm{x}+\mathrm{e}$ $=15,636+1,034 . \mathrm{X}+\mathrm{e}$. Keterangan: $\mathrm{Y}=\mathrm{Citra} ;$ dan $\mathrm{X}=$ customer relationship management (CRM). Dari persamaan ini dapat diinterpretasikan:

1) Dari hasil persamaan regresi di atas diperoleh nilai konstanta sebesar 15,636. Nilai tersebut memiliki makna bahwa jika variabel independent (CRM) bersifat konstans atau tidak berlangsung dengan baik maka nilai citra perbankan sebesar 15,636 skala/satuan.

2) Selanjutnya masih berdasarkan persamaan regresi di atas diperoleh nilai koefisien CRM sebesar 1,034. Nilai tersebut memiliki bahwa setiap penambahan satu nilai CRM akan menaikan nilai citra perbankan sebesar 0,406, atau dengan kata lain apabila CRM semakin baik, maka hal itu akan diikuti pula dengan peningkatan citra perbankan semakin baik pula dengan peningkatan sebesar 0,406.

3) Kemudian berdasarkan persamaan regresi di atas diperoleh pula Nilai Adjusted R Square sebesar 0,360, yang memiliki makna besarnya kemampuan variabel-variabel independent dalam menjelaskan variasi variabel dependent yaitu sebesar $36 \%$, sedangkan sisanya sebesar $64 \%$ dipengaruhi oleh variabel lain yang tidak dimasukan dalam model ini. 


\section{Uji Hipotesis}

Uji hipotesis pada penelitian ini pada dasarnya dilakukan untuk membuktikan apakah variable-variabel yang di kaji pada penelitian terdapat hubungan atau perbedaan dari dua faktor kelompok atau independensi dalam suatu situasi (Ali, H., Limakrisna, N. 2013). Untuk pengujian hipotesis pada penelitian ini dilakukan melalui uji parsial dengan tingkat signifikan 5\%. Dimana pengujian secara parsial melalui uji t dengan membandingkan nilai thitung yang di peroleh dengan nilai $t_{\text {tabel }}$.

Dari hasil uji regresi pada Tabel 1 di atas dengan menggunakan SPSS 21.0 diperoleh angka t hitung variabel CRM sebesar 3,649, dengan nilai signifikansi sebesar 0,000, dikarenakan angka taraf signifikansi $<0,05(0,000<0,05)$ maka dapat disimpulkan bahwa CRM berpengaruh signifikan terhadap citra perbankan. Hal ini dapat diartikan bahwa semakin baik customer relationship management yang ada pada BNI KC Simpang Rimbo Kota Jambi, maka hal ini akan diikuti pula dengan semakin meningkatnya citra bank BNI. Sebaliknya semakin buruknya customer relationship management yang ada pada BNI, maka hal ini akan berdampak terhadap semakin buruknya citra bank BNI.

Setyaleksana, B.Y., Suharyono., dan Yulianto, E (2017) dalam penelitiannya yang mengungkapkan bahwa CRM dapat membentuk citra perusahaan yang positif di benak pelanggan. Selain itu Kamaludin., Tjuparmah, Y., dan Silvana, H (2019) dalam penelitiannya juga menyimpulkan bahwa terdapat pengaruh yang positif dan signifikan dari customer relationship management terhadap citra UPT Perpustakaan Institut Teknologi Bandung baik dari aspek data dan teknologi, sumber daya manusia, maupun proses customer relationship management.

Relationship management merupakan sebuah proses dimana suatu perusahaan membangun aliansi jangka panjang dengan pelanggan dan calon pelanggan, bekerja sama untuk mencapai satu tujuan yang ditentukan. Tujuan tersebut dipenuhi dengan memahami kebutuhan pelanggan, memperlakukan pelanggan sebagai mitra, menjamin bahwa pegawai memenuhi kepuasan pelanggan dan memberikan kualitas yang baik kepada pelanggan (Evans dan Lanskin, 2006).

Selain itu, CRM merupakan strategi bisnis inti yang memadukan proses dan fungsi internal, jaringan eksternal untuk menciptakan dan menyampaikan nilai kepada pelanggan untuk mendapatkan keuntungan (Buttle, 2007). CRM didasarkan pada data pelanggan berkualitas dan dimungkinkan dengan adanya teknologi informasi. Dengan demikian CRM dapat disimpulkan sebagai suatu strategi yang dapat digunakan untuk menjalin hubungan baik dengan pelanggan agar mendapat kepuasan terhadap suatu perusahaan atau lembaga tersebut (Kamaludin., Tjuparmah, Y., dan Silvana, H., 2019).

Dari hasil survey yang dilakukan customer relationship management yang ada pada BNI KC Simpang Rimbo Kota Jambi termasuk pada kategori baik. Hal ini menjelaskan bahwasanya responden memberikan persepsi yang baik terhadap customer relationship management yang ada pada BNI KC Simpang Rimbo Kota Jambi. Artinya BNI KC Simpang Rimbo Kota Jambi dapat berhubungan yang baik dengan nasabahnya. Dengan selalu menjalin komunikasi yang baik dengan nasabahnya, senantiasa komitmen pada nasabahnya memberikan pelayanan terbaik, serta terus berupaya membangun kepercayaan bagi nasabahnya untuk senantiasa selalu menggunakan jasa bank BNI.

\section{KESIMPULAN}

Berdasarkan hasil penelitian dan pembahasan, maka dapat disimpulkan bahwa terdapat pengaruh yang signifikan customer relationship management terhadap citra bank secara parsial. Hal ini dapat diartikan bahwa semakin baik customer relationship management yang 
ada pada sebuah perbankan, maka hal ini akan diikuti pula dengan semakin meningkatnya citra bank. Sebaliknya semakin buruknya customer relationship management yang ada pada sebuah perbankan, maka hal ini akan berdampak terhadap semakin buruknya citra bank perbankan.

\section{DAFTAR RUJUKAN}

Adikaram, C. N. K., \& Khatabi, A. (2016). The Relationship between Customer Relationship Management and Customer Satisfaction: A Study on Private Higher Education Institutions in Sri Lanka. 5(2), 69-95.

Al-dmour, H., \& Hayat, H. K. (2019). The Role of Customer Satisfaction on Enhancing the Relationship between Customer Relationship Management and Customer Loyalty: An Empirical Study on Private Kuwaiti Fitness Gyms. International Business and Management, 2(3), 1-15.

Ali, H. (2012). Membangun Citra Perbankan Melalui IT \& CRM Untuk Meningkatkan Loyalitas Nasabah. Yogyakarta: Hasta Cipta Mandiri.

Ali, H., dan Limakrisna, N. 2013. Metodologi Penelitian (Petunjuk Praktis untuk Pemecahan Masalah Bisnis, Penyusunan Skripsi, Tesis, dan Disertasi). Deeppublish: Yogyakarta.

Balaji, M. S. (2015). Investing in customer loyalty: The moderating role of relational chara cteristics.

Balmer, J. (1995). Corporate Branding and Connoisseurship. Journal of General Management, 21(1), 24-46.

Balmer, J., \& Stotvig, S. (1997). Corporate identity and private banking: a review and case study. International Journal of Bank Marketing, 15(5), 169-184.

Buttle, F. (2007) Customer Relationship Management (Manajemen Hubungan Pelanggan). Jakarta: Bayumedia Publishing

Cornelissen, J. (2000). Corporate image: an audience centred model. Corporate Communications: An International Journal, 5(2), 119-125.

Evans, J.R., and Lanskin. (2006). The Relationship Marketing Process A Conceptualization and Aplication. Industrial Markeitng Management.

Gronroos, C. (2001). The Perceived Service Quality Concept - a mistake?. Journal of Managing Service Quality, Volume 11, No. 3, pp. 150-152, MCB University Press, London.

Iriandini, A.P., Yulianto, E., dan Mawardi, M.K. (2015). Pengaruh Customer Relationship Management (Crm) Terhadap Kepuasan Pelanggan Dan Loyalitas Pelanggan (Survey pada Pelanggan PT. Gemilang Libra Logistics, Kota Surabaya). Jurnal Administrasi Bisnis (JAB)|Vol. 23 No. 2.

Kamaludin., Tjuparmah, Y., dan Silvana, H. (2019). Pengaruh customer relationship management (CRM) terhadap citra perpustakaan pada UPT Perpustakaan ITB. Jurnal Manajemen Komunikasi, Volume 4, No. 1.

Kotler, P. dan Keller, K.L. (2012). Manajemen Pemasaran. Jilid 1 dan 2. Jakarta: PT Indeks.

Moore, F. (2005). Humas (membangun citra dengan komunikasi). Bandung: PT Remaja Rosda Karya.

Ndubisi, N.O. (2007). Relatiosnhip Marketing and Customer Loyalty. Marketing Intelligence \& Planning Vol. 25 No. 1, Emerald Group Publishing Limited. 
Schiffman, L.G., \& Kanuk, L.L. (2010). Consumer Behaviour (10th ed). New Jersey, Pearson Prentice Hall.

Setyaleksana, B.Y., Suharyono., dan Yulianto, E. (2017). Pengaruh Customer Relationship Management (Crm) Terhadap Kepuasan Dan Loyalitas Pelanggan (Survei pada Pelanggan GraPARI Telkomsel di Kota Malang). Jurnal Administrasi Bisnis (JAB), Vol. 46 No.1.

Simamora, E.S. (2007). Analisis Faktor-Faktor Yang membangun Kepuasan Nasabah Untuk Meningkatkan Loyalitas Pelanggan. (Studi Empiris Nasabah PT. Bank Tabungan Negara Cabang Semarang). Tesis Universitas Diponegoro Semarang.

Supranto. J. (2011). Pengukuran Tingkat Kepuasan Pelanggan Untuk Menaikkan Pangsa Pasar. Jakarta: Rineka Cipta.

Tjiptono, F. (2011). Perspektif Manajemen dan Pemasaran Kontemporer. Yogyakarta: Andi.

Tunggal, A.W. (2008). Dasar-Dasar Customer Relationship Management (CRM). Jakarta: Harvindo.

Worcester, R. M. (1997). Managing the image of your bank: the glue that binds. International Journal of Bank Marketing, 15(5), 146-152.

Yandi, A. (2019). Meningkatkan Kepuasan Nasabah Melalui Kualitas Pelayanan yang di Mediasi oleh Kepercayaan (Survey Pada BRI Kcp Unit Kuamang Kuning Kabupaten Bungo). J-MAS (Jurnal Manajemen Dan Sains). https://doi.org/10.33087/jmas.v4i1.83 